\title{
Ban on the Hijab at School: Human Rights Against Migration Background
}

\author{
Nataliya S. Semenova ${ }^{1}$ \\ Ekaterina V. Kiseleva1
}

${ }^{1}$ Department of International Law, Law Institute, Peoples' Friendship University of Russia, Moscow, Russia Corresponding Author: semenovanataliya@mail.ru

\section{Doi:10.5901/mjss.2015.v6n4s1p509}

\section{Abstract}

Russia has only recently faced the problem of wearing hijabs in educational organizations within the last three years, while in Western Europe the debate on this issue has not subsided for several decades. Due to the fact that the common position has not been worked out, it seems important to examine the compliance of the ban on wearing Islamic headscarves in educational institutions with international instruments enshrining the right to education and freedom of conscience and religion, to analyze the position of the Russian Federation through the example of specific legal measures undertaken to solve the situation within the Stavropol region and the latest document published by the Interreligious Council of Russia (issued on March 26, 2015), as well as to analyze the opinion of the European Court of Human Rights stated in the case "Leyla Sahin against Turkey" (2005). A separate issue on the topic concerns the proportionality of the rules on hijabs in their application to and their effect on local and migrant populations of certain states.

Keywords: international law, human rights, education, religion, migration, right to education, right to conscience, thought and religion, traditional values, discrimination, hijab.

\section{Introduction}

In October 2012, a conflict arose in respect of wearing Muslim headscarves (hijabs) by several rural schoolgirls in the Stavropol region of the Russian Federation. Refusal by the parents to accept headscarves for their daughters instead of the hijab resulted in prohibition, for the girls wearing hijabs, to attend classes.

In this case several human rights were at stake. Firstly, it is the right to freedom of conscience and religion. It reads, "[e]veryone shall have the right to freedom of thought, conscience and religion. This right shall include freedom to have or to adopt a religion or belief of his choice, and freedom, either individually or in community with others and in public or private, to manifest his religion or belief in worship, observance, practice and teaching" (para. 1 Art. 18 of the International Covenant on Civil and Political Rights 1966 (hereinafter ICCPR)). Therefore, the question was whether the ban on hijabs in schools limited this right. If so, would it be possible to consider this limitation within the framework of para. 3 Art. 18 of the ICCPR, which reads "[f]reedom to manifest one's religion or beliefs may be subject only to such limitations as are prescribed by law and are necessary to protect public safety, order, health, or morals or the fundamental rights and freedoms of others".

The second aspect touches upon the State's observance of para. 4 Art. 18 of the ICCPR, that says "[t]he States Parties to the present Covenant undertake to have respect for the liberty of parents and, when applicable, legal guardians to ensure the religious and moral education of their children in conformity with their own convictions." This paragraph of the ICCPR clearly establishes the relationship between the right to freedom of conscience and the right to education. The right to education is to be found in Article 13 of the International Covenant on Economic Social and Cultural Rights of 1966 (hereinafter ICESCR). According to para. 3 Art. 13 of the ICESCR "[t]he States Parties to the present Covenant undertake to have respect for the liberty of parents and, when applicable, legal guardians ... to ensure the religious and moral education of their children in conformity with their own convictions". Thus, this part of para. 3 Art. 13 of the ICESCR is identical to para.4 Art. 18 of the ICCPR, confirming thereby a close relationship of religious beliefs with the implementation of the right to education, including the freedom of parents to educate their children in conformity with their own convictions (Abashidze, A.Kh. \& Klishas, A.A., 2013, p. 251-255). In the context of the above example it is clear that the children will conform to the will of their parents.

Due to the fact that girls in hijabs were not admitted to classes, the third aspect of this problem questions whether the ban on headscarves in schools violated the right to education (Semenova, N.S., 2014, p. 34-43), and whether it was 
possible to consider the ban as gender discrimination in the implementation of the right to education.

\section{Method}

The approach of the authors to the issues discussed in the present article is based upon the comparative research into the law of several states, as well as international law. The paper includes analysis of the relevant case of the European Court on Human Rights (hereinafter ECtHR) and the most recent national documents concerning the questions raised.

In most states of Western Europe the question of the ban on hijabs concerns mainly primary and secondary levels of education, though several states also include rules on higher education (materials and examples of state practice used below have been taken from the Judgment of the European Court of Human Rights from November 10, 2005, in the case "Leyla Sahin against Turkey" (complaint No. 44774/98), see also Janis, M.W., Kay, R.S., Bradley A.W., 2008).

There is an interesting example from France, where on $15 \mathrm{March}, 2004$, legislation on the issue of wearing signs or dresses manifesting a religious affiliation in State primary and secondary schools was passed (Code de l'éducation, 2004). The law added a new Article L. 141-5-1 in the Education Code that stated "[i]n State primary and secondary schools, wearing of signs or dress by which pupils overtly manifest a religious affiliation is prohibited". The Act applies to all State schools and educational institutions, except State universities. In addition, as a circular of 18 May 2004 makes clear, it only concerns "... signs, such as the Islamic headscarf, however named, the kippa or a cross that is manifestly oversized, which make the wearer's religious affiliation immediately identifiable" (Loi, 2004).

In Belgium there is currently no general ban on wearing religious signs in schools. Within the French and Flemish Communities there are different rules. There is no uniform policy even inside a single Community. According to national legislation, restrictions may be imposed by school rules on whether to allow religious or philosophical signs to be worn. Some schools do impose such rules, others do not. Pupils are generally allowed to wear religious signs. However, they may do so, only if human rights, the reputation of others, national security, public order and public health and morals are protected and providing that internal rules are complied with.

In Austria, Germany, the Netherlands, Spain, Sweden, Switzerland and the United Kingdom, State education authorities permit Muslim pupils and students to wear the Islamic headscarf.

In Austria there is no special legislation governing the issue of wearing the headscarf, but generally it is considered that a ban on wearing the headscarf will only be justified, if the headscarf poses a health or safety threat to pupils.

There is also an instructive case that took place in 1988 in the UK Altrincham Grammar School. This case ended with a compromise between the private school and family members of the two sisters who wished to be allowed to wear the Islamic headscarf at the respective school. The school agreed to allow them to wear the headscarf, provided it was navy blue (in compliance with school uniform colour), kept fastened at the neck and not decorated.

In Spain there is no explicit statutory prohibition on pupils wearing religious headscarves in State schools, but the school governors have power to issue school rules, which may include provisions on dress codes and standards.

In the Netherlands, Sweden and Finland there is no binding directive regarding a ban on wearing the hijab, but a ban on the burka is regarded as justified by the need of identification of and communication with pupils. Additionally, in the Netherlands the Equal Treatment Commission ruled in 1997 that a ban on wearing the veil was not discriminatory.

Thus, we can say that there is no common European position relating to wearing the hijab at school. However, the common approach to solving this problem is, in most cases, to regulate this question by schools' acts establishing requirements for clothing. In addition, it is important to take into account the rights of others, national security, public order, public health and morals. At the moment, France is the only country that has established a ban on wearing hijabs in schools at the state level.

\section{Results}

In respect of the position of the Russian Federation, it is necessary to determine the legal basis for combatting gender discrimination in the field of education at the international level and in the Russian Federation.

At the international level, there is a number of documents recognizing the right to education (Semenova, N., 2010, p. 35-45) and prohibiting discrimination in education (Beiter, K.D., 2006).

The prohibition of discrimination in education is set in the UNESCO Convention against Discrimination in Education, 1960, which enshrines general provisions on the measures that the States Parties undertake to adopt in order to combat discrimination in education (Kartashkin, V.A., 2012, p. 3-9). In accordance with Article 1 of the Convention the term "discrimination" includes any distinction, exclusion, limitation or preference which, being based on sex, has the 
purpose or effect of nullifying or impairing equality of treatment in education and in particular of depriving any person or group of persons of access to education of any type or at any level (para.1 a). Furthermore, under Article 10 of the Convention on the Elimination of All Forms of Discrimination against Women, 1979, all States Parties "shall take all appropriate measures to eliminate discrimination against women in order to ensure to them equal rights with men in the field of education". As a Party to this Convention the Russian Federation has to fulfill the aforementioned obligations.

At the national level, according to Article 43 of the Constitution of the Russian Federation (1993) "1. Everyone shall have the right to education. / 2. Guarantees shall be provided for general access to and free pre-school, secondary and high vocational education in state or municipal educational establishments and at enterprises". Therefore, in Russia the right to education, including free access to all levels except for higher education, must be guaranteed and secured for everyone without discrimination. A free higher education in state educational organizations is guaranteed for everyone without discrimination on a competitive basis (art. 43(3) of the Constitution).

This is also confirmed by Article 2 of the Constitution of the Russian Federation, which states that "the recognition, observance and protection of the rights and freedoms of a person and citizen shall be the obligation of the State".

Basic general education is compulsory. Parents shall enable their children to receive a basic general education (art. 43(4) of the Constitution). This provision means that parents have a duty to provide education for all children, equally boys and girls. The relevant provisions are also contained in the Federal Law (2012) "On Education in the Russian Federation". Article 3 of the Law establishes the right to education for everyone and the principle of non-discrimination in education.

Thus, we can say that the law contains all guarantees for the elimination of discrimination in education.

Analyzing the conflict in the Stavropol region, it should be noted that the Russian Federation is a multiethnic and polyconfessional country. However, the primary religion is Orthodox Christianity. It should also be highlighted that the covered head of a woman is the provision of religious practice for not only Muslims but for Christians as well (1 Corinthians 11:3-16 taken in conjunction with 1 Thessalonians 5:16-18).

The case was as follows: Girls were coming to school in ordinary headscarves since the beginning of the academic year, i.e. since the $1^{\text {st }}$ September, without any objection from the school administration. In October 2012, parents of the girls decided that the girls should go to school in religious headscarves (hijabs). The school administration subsequently banned wearing religious headscarves at school. As the school director Marina Savchenko said, girls are not allowed to attend lessons in Muslim headscarves because it conflicts with the charter of the school that requires all pupils to wear the same form of clothing. "We did not insist on the fact that they do not put on a hijab at all, but offered to replace it with a headscarf during the time that the girls were in the classroom" (Stavropol school didn't debar schoolgirls in hijabs from attending classes, 2012).

It should be noted that the Islamic tradition clearly states that a woman's head should be covered, but it does not specify what kind of headscarf should there be. Interpreters of texts say only that it should cover the hair and neck. Thus, the hijab headscarf, steadfastly associated with Islam, is simply a traditional headscarf in certain states professing Islam, but Russia is not a Muslim state.

The conflict could have been resolved much quicker, as it had been before, but the girls' parents did not agree with the given solution. Moreover, a following proposal came not only from the school administration, but from the Stavropol Mufti Muhammad Haji Rakhimov as well. The Mufti encouraged all parties to find a compromise. He is quoted as saying, "We must always protect our believers. But we understand that we are in a secular society, where schools have their charters" (The prosecutor's office in the Stavropol region is dealing with the ban on hijabs in schools, 2012).

The conflict could be resolved as follows: Muslim girls come to school in accordance with the rules of the school, and in order not to violate the Islamic traditions, it suffices to wear an ordinary headscarf (The prosecutor's office in the Stavropol region is currently dealing with the ban on hijabs in schools, 2012). There were more than 300 pupils at the school where the conflict arose. The majority of girls practicing Islam were always wearing headscarves while at school following their religious traditions and school charter (The prosecutor's office in the Stavropol region is currently dealing with the ban on hijabs in schools, 2012). Therefore, a compromise was found which was consistent with European practice. Thus, it can hardly be said that the school director forced the girls and their parents into a violation of their religious traditions.

The Ministry of Education for the Stavropol Territory supported the position of the school director, because the school charter pre-approved the clothing requirements for all pupils.

As parents insisted on their position, the public authorities took several measures. The Government of the Stavropol Territory took the decision to ban girls from Muslim families from coming to school wearing religious headscarves (hijabs).

The parents appealed against this decision to a court, including the Supreme Court of the Russian Federation. 
The Stavropol Regional Court declared the decision of the Government of Stavropol Territory lawful. And then, on 10 July 2013, the Supreme Court of Russia agreed with the Government of the Stavropol Territory banning girls from Muslim families from coming to school wearing religious headscarves (hijabs). Thus, the Court found no violation of the right to education and no gender discrimination in education relating to a ban on wearing the hijab.

President Vladimir Putin also supported the decision and upheld the view given by the courts. On the issue of wearing religious headscarves (hijab) at school, he said, "There is nothing good about that. There are, of course, the national peculiarities in the national republics. But it is a demonstration of the well-known relationship to religion. In our country and in the Muslim regions specifically there is no such tradition ("Hijab? There is nothing good about that!" - Putin answers the questions of Russians, 2013).

This case has influenced public policy regarding education (Gender issues and traditional values in the light of international law: Roundtable discussion on April 12 and October 10, 2014, during the XII Annual International Scientific and Practical Conference "Topical problems of contemporary international law", commemorating Professor I.P.Blischenko, 2015). For example, in April 2013, a bill on school uniforms for all pupils in state educational organizations was introduced in the State Duma (Lower chamber of the Russian Parliament). Under the bill, each region had to set requirements for clothing at schools. As noted by the State Duma deputy Olga Timofeeva, "We enable the regions to establish uniform requirements for the clothing of pupils, taking into account local circumstances as well as the wishes of schools, students and their parents." Requirements should be established in order to provide pupils with comfortable and aesthetic clothing shaping their sense of belonging to the educational organization and to improve the mental attitude of pupils at school, secure the secular character of education, eliminate the signs of social status, wealth and religious differences among pupils and to strengthen their unity and discipline (A bill on the introduction of school uniforms introduced in the State Duma, 2013). It should be noted that Article 4 of the Federal Law (1997) "On Freedom of Conscience and Religious Associations" states that in accordance with the constitutional principle of the separation of religious associations from the state, the state provides a secular education in state educational organizations.

Since 1 September 2013 the Russian regions have introduced mandatory requirements for pupils' clothing. At the federal level the uniform requirements for the appearance of pupils and school uniforms have also been adopted. Uniform requirements apply to all regions, but each of the regions issues a normative act, detailing the federal provisions, taking into account the climatic characteristics and traditions of a particular locality in developing requirements for school uniforms.

In the Stavropol region common rules for the appearance of pupils were likewise introduced. This does not mean the same uniform for all, but all clothing must meet certain requirements. Similar requirements for the appearance of pupils have been introduced in a number of regions of the country, including Bashkortostan, Dagestan and Adygea.

It is important to note that these requirements apply only to schools and do not apply to universities.

Finally, on 4 June 2014 the Federal Law (2014) "On Amending the Federal Law "On Education in the Russian Federation"'" (so called "law on school uniform") was adopted. Article 38 of the Federal Law (2012) "On Education in the Russian Federation" was amended as follows: "Pupils' clothes. Uniforms and other clothing and equipment (outfit) of pupils". Under this article:

1. "Organizations engaged in educational activities have the right to establish clothing requirements for students, including the requirements for general appearance, color, style, type of students clothing, insignia and the rules regarding wearing of the said clothes, unless otherwise provided by this Article. Appropriate local normative act of organization engaged in educational activities shall take into account the opinion of the Board of students, the Board of parents, as well as the employees' representative body for the organization or of its students (if any).

2. State and local organizations engaged in educational activities on educational programs of primary general, basic and secondary education must establish requirements for clothing of pupils in accordance with the standard requirements approved by the authorized state bodies of subjects of the Russian Federation..."

Consequently, the situation was finally solved. Pupils in public schools are now required to abide by the rules established by their respective school.

For the children whose parents feel the need for their children to wear religious clothing there is an option allowing them to freely choose the type of education that best suits their needs: family, part-time, evening form of education or externship. It is also possible to send children to private schools.

In 2015, the wearing of religious symbols was, inter alia, referred to by the Interreligious Council of Russia. The Council was established in December of 1998 at the joint meeting of the heads of Orthodox Christian, Muslim, Jewish and Buddhist religious communities of Russia. The Honorary Chairman of the Council is the Patriarch of Moscow and All Russia, and the main governing body - The Presidium of the Council headed by the Honorary Chairman - gathers the 
heads of traditional religious organizations of the country. On the $26^{\text {th }}$ of March, 2015 , the Interreligious Council of Russia adopted a seven-paragraph Statement in respect of discussions around external expressions of piety (2015). Paragraph 2 of the Statement refers to Article 18 of the Universal Declaration of Human Rights that provides for a right to practice one's religion, alone or in a community. The Statement continues with a reminder that "the norms of international law exclude the possibility to allege that the practice of religion shall be 'a private issue' of the believer and that external, societal manifestations of piety are impossible or undesirable" (para. 3). Concerning the central issue of the present article, the Statement says that "[t]he best response to the emerged uneasy discussion were the solutions found in many regions and institutional settings that allowed ... Muslims, Jews and Orthodox Christians to wear head-dresses, not covering a face... Such practice shows that one can find a way out of the most uneasy situations with dignity" (para. 6). "The Interreligious Council of Russia calls for the state bodies and the whole society to honour the rights of believers to express their piety and to renounce any attempts to impose norms of behavior contradicting one's beliefs. Simultaneously, the participants of the meeting call the believing people /to monitor their behaviour so/ that any action and discussion arising around them served not a division, but creation of civil peace" (para. 7).

Concluding, it is important to note that to date there is no prohibition on wearing headscarves at school provided for in federal laws. The main requirement is that the headscarf is not religious in nature. An ordinary headscarf is not religious, so children can wear it, if that is a part of the school uniform, at the request of parents. So, children who profess Islam can study in public schools without violating the rules of Islam.

\section{Discussion}

Due to the fact that the parents of the girls from the Stavropol school were considering appealing the judgment of the Russian court to the ECtHR it is important to summarize the position of the ECHR on this matter. It is reflected in the ECtHR's Judgement from November 10, 2005, in the case of "Leyla Sahin against Turkey" (complaint No. 44774/98). It should be noted that the case concerned the ban on wearing a hijab at a university, but the Court examined in detail the circumstances of the ban, so that the conclusions drawn by analogy can be applied to schools.

The applicant was born in 1973, coming from a traditional family of practicing Muslims. She considered it to be her religious duty to wear the Islamic headscarf. On August 26, 1997, the applicant, then in her $5^{\text {th }}$ year at the Faculty of Medicine at Bursa University, was enrolled on the Cerrahpaşa Faculty of Medicine at Istanbul University. She wore the Islamic headscarf during the four years she spent studying medicine at the University of Bursa and continued to do so until February 1998. On February 23, 1998, the Vice-Chancellor of Istanbul University issued a circular, the relevant part of which stated that "students whose 'heads are covered' (who wear the Islamic headscarf) ... must not be admitted to lectures, courses or tutorials". On 12 March 1998, in accordance with the aforementioned circular, the applicant was denied access to a written examination on oncology because she was wearing the Islamic headscarf. On 20 March 1998 the secretariat of the chair of orthopaedic traumatology refused to enroll her; on 16 April 1998 she was refused admission to a neurology lecture and on 10 June 1998 to a written examination on public health, all for the same reason. After some attempts to challenge the decisions Leyla Sahin left Istanbul to pursue her medical studies at the Faculty of Medicine at the University of Vienna.

Firstly let us consider the Turkish law on this issue. On 3 December 1934 Turkey adopted the Law no. 2596, concerning dress, which imposed a ban on wearing religious attire other than in places of worship or at religious ceremonies, irrespective of the religion or belief concerned. Therefore, this law forbade wearing the hijab.

Nevertheless, in Turkey during the 1980s, a tradition of wearing Islamic headscarves at schools and universities began to emerge. The first piece of legislation on dress in institutions of higher education was a set of regulations issued by the Cabinet on 22 July 1981 requiring staff working for public organizations and institutions and personnel and female students at State institutions to wear ordinary, sober, modern dress. On 20 December 1982 the Higher Education Authority issued a circular on the wearing of headscarves in institutions of higher education. The Islamic headscarf was thereafter banned in lecture theatres. In a judgement of 13 December 1984, the Supreme Administrative Court held that the regulations were lawful, noting "[b]eyond being a mere innocent practice, wearing the headscarf is in the process of becoming the symbol of a vision that is contrary to the freedoms of women and the fundamental principles of the Republic".

According to Turkish opinion, everyone was free to choose how to dress, as the social and religious values and traditions of society also had to be respected. However, when a particular dress code was imposed on individuals by reference to a religion, the religion concerned was perceived and presented as a set of values that were incompatible with those of contemporary society. In addition, in Turkey, where the majority of the population was Muslim, presenting the wearing of the Islamic headscarf as a mandatory religious duty would result in discrimination between practicing 
Muslims, non-practicing Muslims and non-believers on grounds of dress with anyone who refused to wear the headscarf undoubtedly being regarded as opposed to religion or as non-religious.

The Constitutional Court also said that students had to be permitted to work and pursue their education together in a calm, tolerant and mutually supportive atmosphere without being deflected from that goal by signs of religious affiliation. The Constitutional Court found that, irrespective of whether the Islamic headscarf was a precept of Islam, granting legal recognition to a religious symbol of that type in institutions of higher education was not compatible with the principle that State education must be neutral, as it would be liable to generate conflicts between students with differing religious convictions or beliefs. The Constitutional Court also stated that in institutions of higher education the wearing of a veil or hijab on grounds of religious conviction is contrary to the principles of secularism and equality enshrined in the Constitution of Turkey. As a result, the Constitutional Court issued a decision prohibiting the wearing of religious clothing at universities.

The ECtHR found that the Istanbul University regulations restricting the right to wear the Islamic headscarf and the measures taken thereunder had interfered with the applicant's right to manifest her religion. But it went on to find that the interference was prescribed by law and pursued one of the legitimate aims set out in the second paragraph of Article 9 of the Convention for the Protection of Human Rights and Fundamental Freedoms 1950 (hereinafter Convention or ECHR). According to this Article, "1 (See http://conventions.coe.int/Treaty/en/Treaties/Html/005.htm). Everyone has the right to freedom of thought, conscience and religion; this right includes freedom to change his religion or belief and freedom, either alone or in community with others and in public or private, to manifest his religion or belief, in worship, teaching, practice and observance. 2. Freedom to manifest one's religion or beliefs shall be subject only to such limitations as are prescribed by law and are necessary in a democratic society in the interests of public safety, for the protection of public order, health or morals, or for the protection of the rights and freedoms of others".

According to ECtHR's opinion, this interference was "justified in principle and proportionate to the aims pursued and could therefore be regarded as having been necessary in a democratic society".

The ECtHR also noted that Article 9 does not protect every act motivated or inspired by a religion or belief. In democratic societies, in which several religions coexist within one and the same population, it may be necessary to place restrictions on the freedom to manifest one's religion or belief in order to reconcile the interests of the various groups and ensure that all parties' beliefs are respected. This follows both from paragraph 2 of Article 9 and the State's positive obligation under Article 1 of the Convention to secure the rights and freedoms defined therein to everyone within the state's jurisdiction.

Taking into account all circumstances of the case and the national courts' decisions, the ECtHR found that the interference complained of pursued mainly the legitimate aim of protecting the rights and freedoms of others and public order. Consequently, there had been no breach of Article 9 of the Convention.

The ECtHR also considered, separately, the alleged violation of Article 2 of Protocol No. 1 of the Convention, which covers the right to education. According to this Article, "No person shall be denied the right to education. In the exercise of any functions which it assumes in relation to education and to teaching, the State shall respect the right of parents to ensure such education and teaching in conformity with their own religions and philosophical convictions".

The right to education is guaranteed to everyone and covers "a right of access to educational institutions existing at a given time". However, such access constitutes only a part of the right to education. For that right "to be effective, it is further necessary that, inter alia, the individual who is the beneficiary should have the possibility of drawing profit from the education received, that is to say, the right to obtain, in conformity with the rules in force in each State, and in one form or another, official recognition of the studies which he has completed". Moreover, implicit in the phrase "No person shall..." is the principle governing the equality of treatment of all citizens in exercising their right to education.

The right to education, however, is not absolute, but may be subject to limitations. These are permitted since the right of access "by its very nature calls for regulation by the State". The regulation of educational institutions may vary in time and in place according to the needs and resources of the community and the distinctive features of different levels of education. Consequently, the Contracting States enjoy a certain margin of appreciation in this sphere.

The ECtHR, by analogy with its reasoning on the question of the existence of interference under Article 9 of the Convention, accepted that the regulations on the basis of which the applicant was refused access to various lectures and examinations for wearing the Islamic headscarf constituted a restriction on her right to education, notwithstanding the fact that she had had access to the university and been able to read the subject of her choice in accordance with the results she had achieved in the university entrance examination.

However, an analysis of the right to education cannot in this instance be divorced from the conclusion reached by the ECtHR with respect to Article 9 of the ECHR. Therefore, as the considerations taken into account under that provision are clearly applicable to the complaint under Article 2 of Protocol No. 1, the ECtHR has already found that the restriction 
was foreseeable to those concerned and pursued the legitimate aims of protecting the rights and freedoms of others and maintaining public order. The obvious purpose of the restriction was to preserve the secular character of educational institutions.

Regarding the principle of proportionality, the ECtHR found that there was a reasonable relationship of proportionality between the means used and the aim pursued. In so finding, The Court relied in particular on the following factors that are clearly relevant here. Firstly, the measures in question manifestly did not hinder the students in performing the duties imposed by the habitual forms of religious observance. Secondly, the decision-making process for applying the internal regulations satisfied, as far as was possible, the requirement to weigh up various interests at stake. The university authorities judiciously sought means whereby they could avoid having to turn away students wearing the headscarf and, at the same time, honour their obligation to protect the rights of others and the interests of the education system. Lastly, the process also appears to have been accompanied by safeguards, including the rule requiring conformity with statute and judicial review, which were apt to protect the students' interests. Consequently, the restriction in question did not impair the very essence of the applicant's right to education.

It is important to mention a dissenting opinion of Judge Tulkens. According to Judge Tulkens, the applicant did not, on religious grounds, seek to be excused from certain activities or request changes to be made to the university course for which she was enrolled as a student. She simply wished to complete her studies in the conditions that existed when she was first enrolled at the university and during the initial years of her university career, when she had been free to wear the headscarf without any problem. In this regard, Judge Tulkens considerd that by refusing the applicant access to the lectures and examinations that were part of the course at the Faculty of Medicine, she was de facto deprived of the right of access to the university and, consequently, of her right to education. Consequently, the reasons which led the ECtHR to conclude that there has been no violation of Article 9 of the Convention or Article 2 of Protocol No. 1 incontestably apply to the complaint under Article 14, taken alone or in conjunction with the aforementioned provisions. Thus, the ECtHR held that there has been no violation of Articles 8,10 or 14 of the Convention. Thus, despite the dissenting opinion of Judge Tulkens, the position of the ECtHR on the question of the hijab is unambiguous, making it futile to appeal to it to protect the interests on this subject.

\section{Acknowledgement}

The paper is prepared with the assistance of the Russian Fund for Humanities, project No. 14-33-01040.

\section{References}

A bill on the introduction of school uniforms introduced in the State Duma. (2013). Ansar. 23.04.2013. Retrieved from http://www.ansar. ruleducation/2013/04/23/40108.

Abashidze, A.Kh. \& Klishas, A.A. (2013). Protection of human rights and freedoms in accordance with the International legal standards in the context of new realities of the globalized world. Herald of the Peoples' Friendship University of Russia. Law. 2, 251-255.

Beiter, K.D. (2006). The Protection of the Right to Education by International Law: Including a Systematic Analysis of Article 13 of the International Covenant on Economic, Social and Cultural Rights. Martinus Nijhoff Publishers. - 776 pp.

Code de l'éducation. (2004). Article L141-5-1 Retrieved from http://www.legifrance.gouv.fr/affichCodeArticle.do;jsessionid=EED7F4F0 C59C7E5FA6BFDDC77B47A35A.tpdj007v_3?cidTexte=LEGITEXT000006071191\&idArticle=LEGIARTI000006524456\&dateText e=20150130\&categorieLien=id\#LEGIARTI000006524456.

Constitution of the Russian Federation. (1993). Retrieved from http://www.constitution.ru/en/10003000-01.htm.

Federal Law (1997) "On Freedom of Conscience and Religious Associations" No. 125-FZ. Retrieved from http://www.consultant.ru/ document/cons_doc_LAW_170122/.

Federal Law (2012) "Onn Education in the Russian Federation" No. 273-FZ. Retrieved from http://www.rg.ru/2012/12/30/obrazovaniedok.html.

Federal Law (2014) "On Amending the Federal Law "On Education in the Russian Federation"'" No. 148-FZ. Retrieved from http://www.referent.ru/1/232658.

Gender issues and traditional values in the light of international law: Roundtable discussion on April 12 and October 10, 2014, during the XII Annual International Scientific and Practical Conference "Topical problems of contemporary international law", commemorating Professor I.P.Blischenko. (2015). Ed. by Abashidze, A.Kh., Semenova, N.S., Kiseleva, E.V., Alisievich, E.S. Moscow: Pokrov PRO, 2015. - 240 p.

"Hijab? There is nothing good about that!" - Putin answers the questions of Russians. (2013). Retrieved from http://www.ansar.ru/ sobcor/2013/04/25/40180.

Janis, M.W., Kay, R.S., Bradley A.W. (2008). European human rights law: Text and materials. 3rd ed. New York: Oxford University Press, 2008. - 957 pp.

Kartashkin, V.A. (2012). Universalization of human rights and the traditional values of mankind. Modern Law. 8, 3-9. 
Loi (2004) encadrant, en application du principe de laïcité, le port de signes ou de tenues manifestant une appartenance religieuse dans les écoles, collèges et lycées publics $n^{\circ}$ 2004-228 du 15 mars 2004. Retrieved from http://www.legifrance.gouv.fr/eli/loi/ 2004/3/15/2004-228/jo/texte.

The prosecutor's office in the Stavropol region is dealing with the ban on hijabs in schools. (2012). Kavkaz-Uzel. Retrieved from http://www.m.kavkaz-uzel.ru/articles/214196/?page=2.

Semenova, N. (2010). The right to education in international law. International Law. 3, 31-40.

Semenova, N.S. (2014). International legal protection of traditional values: Realization of the right to education. Obozrevatel-Observer. 7 , 34-43.

Statement in respect of discussions around external expressions of piety (2015), adopted by the Interreligious Council of Russia on 26 March, 2015. Retrieved from http://interreligious.ru/dokumenty/vyrazhenie-religioznosti/.

Stavropol school didn't debarr schoolgirls in hijab from attending classes. (2012). Pravda. Retrieved from http://m.pravda.ru/news/ society/15-10-2012/1131381-hidgab-0/. 